\title{
Penerapan Model Pembelajaran Tematik Tema Lingkungan dengan Pendekatan Kontekstual di SD Katolik Yos Sudarso Nusa Tenggara Timur
}

\author{
Bergita \\ Guru di SD Katolik Yos Sudarso Maumere, Sikka, Nusa Tenggara Timur \\ Email: bergita@gmail.com \\ DOI : $10.32672 /$ jsa.v7i5.1527
}

\begin{abstract}
ABSTRAK
Pembelajaran tematik merupakan pembelajaran terpadu yang menggunakan tema sebagai pemersatu materi dalam beberapa mata pelajaran sekaligus dalam satu kali tatap muka. Sehingga membuat proses pembelajaran menjadi lebih bermakna dan dapat dengan mudah dipahami oleh siswa SD khususnya kelas rendah. Akan tetapi banyak guru-guru SD yang masih belum bisa menerapkan model pembelajaran tematik dengan benar dan berhasil. Untuk itu pemahaman pembelajaran tematik para guru perlu ditingkatkan dan mereka harus mengembangkan secara lebih kreatif, inovatif, dan adaptif. Dengan demikian usaha berkelanjutan yang berkaitan dengan pengembangan pembelajaran tematik yang menarik harus dipacu sebagai sarana belajar dan pendewasaan. kesimpulan yaitu sebagai berikut: (a) Penerapan model pembelajaran tematik tema lingkungan dengan pendekatan kontekstual selama proses belajar mengajar yang telah di terapkan peneliti di dalam kelas mampu meningkatkan hasil siswa. Hal ini di tandai dengan ketuntasan belajar siswa yang cukup baik dari hasil tes formulatif pada dua siklus yang di laksanakan mulai dari siklus pertama sampai kedua. Hasil belajar siswa memperoleh ketuntasan nilai 43,3\% dari jumlah siswa pada siklus 1 dan meningkat menjadi 83,3\% dari jumlah siswa pada siklus 2; (b) Penerapan model pembelajaran tematik tema lingkungan dengan pendekatan kontekstual bagi siswa kelas I B di SD Katolik Yos Sudarso ini dapat meningkatkan keaktifan belajar siswa. Hal ini dapat dilihat dari hasil observasi yang mencapai skor rata-rata pada siklus $\mathrm{I}=1,6$ serta perubahan skor rata-rata yang ada pada siklus II $=2,5$. Dari siklus I dan siklus II tersebut sudah jelas ada peningkatan nilai skor rata-rata sebesar 0,9; (c) Penerapan model pembelajaran tematik tema lingkungan dengan pendekatan kontekstual bagi siswa kelas 1 di kelas I B di SD Katolik Yos Sudarso ini dapat meningkatkan standart nilai ketuntasan belajar siswa. Hal ini dapat dilihat dari hasil observasi yang mencapai skor rata-rata pada siklus $\mathrm{I}=1,7$ serta perubahan skor rata-rata yang ada pada siklus II $=2,5$. Dari siklus I dan siklus II tersebut sudah jelas ada peningkatan nilai skor rata-rata sebesar 0,8 .
\end{abstract}

Kata Kunci : Pembelajaran Tematik, Pendekatan Kontekstual, Siswa 
Pada dasarnya pendidikan merupakan suatu proses membimbing manusia dari kegelapan kebodohan menuju kecerahan pengetahuan.Pendidikan adalah "suatu proses dalam rangka mempengaruhi siswa agar dapat menyesuaikan diri sebaik mungkin terhadap lingkungannya dan dengan demikian akan menimbulkan perubahan dalam dirinya yang memungkinkan dapat bermanfaat dalam kehidupan masyarakat nantinya" (Hamalik, 2001 : 79).

Sekolah Dasar (SD) memiliki peran dan manfaat yang sangat penting dalam mempersiapkan sumber daya manusia yang bermutu. Alasan ini didasarkan bahwa dari pendidikan inilah siswa sudah memperoleh dasar-dasar pengetahuan untuk menjembatani mereka dalam meraih cita-cita mereka di masa depan. Oleh karena itu, guru harus dapat kreatif dan tepat dalam memilih model pembelajaran, proses pembelajaran, media pembelajarannya serta materi pembelajarannya haruslah sesuai dengan tingkat perkembangan usia siswa MI. Dengan adanya fenomena seperti inilah maka munculah sistem pembelajaran terpadu yaitu melalui pembelajaran tematik.

Pembelajaran tematik merupakan suatu strategi pembelajaran yang melibatkan beberapa mata pelajaran. Keterpaduan dalam pembelajaran ini dapat dilihat dari aspek proses, waktu, aspek kurikulum, dan aspek belajar mengajar. Jadi, pembelajaran tematik adalah "pembelajaran terpadu yang menggunakan tema sebagai pemersatu materi dalam beberapa mata pelajaran sekaligus dalam satu kali tatap muka. Sehingga membuat proses pembelajaran menjadi lebih bermakna dan dapat dengan mudah dipahami oleh siswa SD khususnya kelas rendah" (Kunandar, 2007: 333).

Akan tetapi banyak guru-guru SD yang masih belum bisa menerapkan model pembelajaran tematik dengan benar dan berhasil. Untuk itu pemahaman pembelajaran tematik para guru perlu ditingkatkan dan mereka harus mengembangkan secara lebih kreatif, inovatif, dan adaptif. Dengan demikian usaha berkelanjutan yang berkaitan dengan pengembangan pembelajaran tematik yang menarik harus dipacu sebagai sarana belajar dan pendewasaan. Tujuannya adalah "untuk mengubah serta menemukan pembelajarannya yang lebih berdaya guna serta meningkatkan hasil belajar siswa" (Sutirjo dan Istuti, 2004: $5)$.

Hasil belajar siswa adalah kemampuan-kemampuan yang dimiliki siswa setelah ia menerima pengalaman belajarnya. Ada tiga macam hasil belajar, yaitu: "(a) keterampilan dan kebiasaan, (b) pengetahuan dan pengertian, (c) sikap dan cita-cita" (Sudjana, 2008: 22). Belajar pada hakikatnya adalah "suatu interaksi antara individu dan lingkungan. Lingkungan menyediakan rangsangan (stimulus) terhadap individu dan sebaliknya individu memberikan respons terhadap lingkungan" (Hamalik, 2001: 194). Hal ini menunjukkan, bahwa fungsi lingkungan merupakan faktor yang penting dalam proses belajar mengajar. Mengingat begitu kompleksnya manfaat dari belajar tentang lingkungan bagi siswa SD, namun pembelajaran lingkungan sudah harus dikenalkan dan diterapkan pada siswa.

Kenyataan yang terjadi saat ini, siswa SD khususnya kelas rendah masih belum peduli dengan keadaan lingkungannya sendiri, karena pada seusia mereka (7 tahun- 9 tahun), mereka selalu asyik dengan dunianya sendiri tanpa memperhatikan lingkungan di sekitarnya. Dengan kondisi ini maka peneliti merasa tertarik untuk melakukan penelitian 
Bergita

dengan menggunakan pendekatan kontekstual di kelas I B SD Katolik Yos Sudarso Maumere.

\section{METODE PENELITIAN \\ Jenis dan Pendekatan Penelitian}

Metode Penelitian pada dasarnya merupakan cara ilmiah untuk mendapatkan data dengan tujuan dan kegunaan tertentu. Penelitian ini menggunakan pendekatan kualitatif. Penelitian kualitatif adalah penelitan yang dimaksudkan untuk "mengungkap gejala secara holistic-kontekstual (secara menyeluruh dan sesuai dengan konteks atau apa adanya) melalui pengumpulan data dari latar alam sebagai sumber langsung dengan instrumen kunci peneliti itu sendiri"(Tanzeh, 2004: 40). Karena dalam penelitian ini tidak mengutamakan hasil akan tetapi lebih mengutamakan proses dari hasil penelitian itu sendiri diantaranya berupa aneka macam cara baik itu meliputi: observasi, wawancara, serta dokumen.

Jenis penelitian yang digunakan adalah Jenis Penelitian Tindakan Kelas (PTK). Arikunto (2009: 3) mendefisinisikan PTK sebagai "suatu pencermatan terhadap kegiatan belajar berupa sebuah tindakan yang sengaja dimunculkan dan terjadi dalam sebuah kelas secara bersama". Karena PTK memiliki peranan yang sangat penting dan strategis untuk meningkatkan mutu pembelajaran apabila dapat menerapkannya dengan baik. "Disini peran seorang guru sangatlah penting karena guru tidak hanya berperan sebagai pengajar saja akan tetapi disini guru juga berperan sebagai pihak peneliti juga yang mana harus dapat memecahkan permasalahan nyata yang terjadi di kelas serta meningkatkan pengembangan profesinya" (Kunandar, $2008: 45$ ).

\section{Lokasi dan Subjek Penelitian}

Penelitian ini terjadi di SD Katolik Yos Sudarso Maumere, yang terletak di Jalan Kesehatan, Kelurahan Beru, Kabupaten Sikka, Provinsi NTT. Alasan peneliti memilih sekolah ini karena sekolah tersebut merupakan tempat tugas peneliti. Adapun subyek penelitian ditetapkan pada siswa kelas I B yang berjumlah 30 orang, dengan rincian siswa laki-laki sebanyak 18 orang dan siswa perempuan sebanyak 12 orang. Subyek siswa yang diteliti diambil pada Tahun Ajaran 2018/2019.

\section{Data dan Sumber Data}

Data adalah bahan nyata yang dapat dijadikan dasar kajian. Data yang dikumpulkan dalam penelitian ini adalah sebagai berikut : (a) Hasil tes siswa, hasil pekerjaan siswa dalam menyeleseikan soal yang diberikan peneliti. Tes diberikan pada awal sebelum penelitian dan tes setelah adanya penelitian; (b) Hasil wawancara, wawancara antara peneliti dan siswa yang dijadikan subyek penelitian sehubungan dengan proses pembelajaran dan pemahaman terhadap materi; (c) Hasil observasi, yang diperoleh dari pengamatan teman sejawat atau guru wali kelas di sekolah tersebut terhadap aktifitas praktisi dan siswa dengan menggunakan lembar pengamatan yang disediakan oleh peneliti; (d) Catatan lapangan, yang berisikan pelaksanaan kegiatan siswa dalam pembelajaran selama penelitian berlangsung; (e) Diskusi dengan guru dan teman sejawat untuk refleksi siklus penelitian tindakan kelas. 
Menurut Arikunto (2006 : 133), "sumber data adalah subyek dari mana data itu diperoleh". Sumber data dalam penelitian ini antara lain: 1) siswa kelas I B SD Katolik Yos Sudarso Tahun Ajaran 2018/2019 untuk mendapatkan data tentang hasil belajar siswa dalam proses belajar mengajar, 2) teman sejawat dimaksudkan sebagai sumber data untuk melihat penerapan penelitian tindakan kelas secara komprehensif baik dari sisi siswa atau guru.

\section{Teknik Pengumpulan Data}

Sesuai dengan data yang akan dikumpulkan dalam penelitian ini,maka tehnik pengumpulan data penelitian ini meliputi: (a) Tes dilakukan untuk mengumpulkan informasi tentang pemahaman siswa terhadap konsep materi yang akan di ajarkan nanti; (b) Wawancara, wawancara dimaksudkan untuk menggali kesulitan siswa dalam memahami konsep materi yang mungkin sulit diperoleh dari hasil pekerjaan siswa atau melalui observasi; (c) Observasi, yaitu "metode atau cara-cara menganalisis dan mengadakan pencatatan secara sistematis mengenai tingkah laku dengan melihat atau mengamati individu atau kelompok secara langsung" (Purwanto, 2002: 14). Pengamat partisipasi dilakukan oleh orang yang terlibat secara aktif dalam proses pelaksanaan tindakan. Dalam kegiatan ini digunakan pedoman observasi. Pemantauan didalam penelitian ini dilakukan dengan tujuan berikut:Mengetahui kesesuaian pelaksanaan tindakan dengan rencana tindakan yang telah ditetapkan peneliti dan guru secara bersamasama; Mendapatkan keterangan atau catatan tertentu tentang aktivitas yang menonjol pada saat pembelajaran berlangsung; Mengetahui pelaksanaan tindakan khususnya perubahan perilaku yang dilakukan guru maupun siswa; (d) Catatan lapangan, yang memuat segala perbuatan penelitian maupun siswa selama proses berlangsung pemberian tindakan. Hasil pencatatan lapangan digunakan untuk melengkapi data.

\section{Teknik Analisis Data}

Proses analisis data dilakukan melalui beberapa tahapan yaitu mulai dari awal pembelajaran, selama pembelajaran, sampai dengan setelah pelaksanaan pembelajaran selesai dilaksanakan. Analisis data diawali dengan mengamati data, dimana peneliti mempelajari serta memeriksa kembali secara menyeluruh data-data yang sudah dikumpulkan, baik itu data perencanaan, pelaksanaan, dan penilain pembelajaran tematik untuk meningkatkan hasil belajar siswa.

Selanjutnya adalah proses penganalisisan data. Pada saat menganalisis data berlangsung disini sudah dapat diketahui antara data yang relevan dengan data yang tidak relevan. Data dikatakan relevan apabila data tersebut berhubungan dengan perencanaan, pelaksanaan, dan penilain prestasi belajar pembelajaran yang terdiri atas beberapa komponen yang sudah ditentukan.

\section{Prosedur Penelitian}


Bergita

Pelaksanaan penelitian ini dibagi dalam II siklus, keputusan ini diambil dari hasil observasi dan wawancara yang dilakukan oleh peneliti baik dari guru kelas I maupun siswa kelas I sebelumnya baik dari segi akademik maupun dari segi non akademiknya, segi aktivitas siswanya dalam proses pembelajarannya.

\section{HASIL PENELITIAN DAN PEMBAHASAN} Deskripsi Data Penelitian Tiap Siklus

Berdasarkan penelitian yang sudah dilakukan oleh peneliti, maka beberapa data yang dikumpulkan pada tiap siklus adalah sebagai berikut:

Tabel 1.Hasil Skor Tes Formatif Siswa pada Siklus I

\begin{tabular}{cccc}
\hline NO. & SKOR & FREKUENSI & PRESENTASE (\%) \\
\hline 1. & 100 & - & - \\
\hline 2. & 95 & 1 & 3,3 \\
\hline 3. & 90 & 3 & 10 \\
\hline 4. & 85 & 2 & 6,7 \\
\hline 5. & 80 & 3 & 10 \\
\hline 6. & 75 & 4 & 13,3 \\
\hline 7. & 70 & 3 & 10 \\
\hline 8. & 65 & 3 & 10 \\
\hline 9. & 60 & 4 & 13,3 \\
\hline 10. & 55 & 4 & 10 \\
\hline 11. & 50 & 3 & 100 \\
\hline
\end{tabular}

Hasil observasi siswa diperoleh dari efektivitas siswa dalam belajar, keaktififan siswa dalam proses pembelajaran, serta standart nilai ketuntasan. Perolehan nilai rata-rata skor aktivitas belajar siswa selama proses pembelajaran berlangsung, dan standart nilai ketuntasan yang ditentukan oleh pihak sekolah tersebut pada siklus I dapat dilihat dari tabel berikut ini:

Tabel 2. Hasil Observasi Siswa pada Siklus I

\begin{tabular}{llll}
\hline No. & Aspek & \multicolumn{3}{c}{ Hal-hal yang diamati } & Nilai Rata-rata \\
\hline 1. & Aktivitas & $\begin{array}{l}\text { Siswa mengikuti jalannya proses } \\
\text { pembelajaran dengan tertib dan disiplin. }\end{array}$ & 1,7 \\
& & $\begin{array}{l}\text { Siswa mau berdiskusi dan bekerjasama } \\
\text { dengan anggota kelompoknya. }\end{array}$ & 1,7 \\
\cline { 3 - 4 } & $\begin{array}{l}\text { Siswa mau dan berani memberikan } \\
\text { tanggapan dan saran terhadap hasil kerja } \\
\text { temannya. }\end{array}$ & 1,5 \\
\hline 2. & $\begin{array}{l}\text { Siswa mendapat nilai minimal memenuhi } \\
\text { nilai }\end{array}$ & 1,8 \\
\hline
\end{tabular}




\begin{tabular}{llc}
\hline ketuntasan & pihak sekolah. & \\
\cline { 2 - 3 } & $\begin{array}{l}\text { Siswa tidak pernah remidi dalam setiap } \\
\text { mengerjakan tugas yang diberikan oleh }\end{array}$ & \\
& guru. & \\
& Jumlah Nilai Rata-rata & 8,3 \\
\hline
\end{tabular}

Perolehan nilai rata-rata dari setiap indikatornya diperoleh dari jumlah total dari setiap indikatornya dikali $100 \%$ dibagi jumlah seluruh siswanya. Dari tabel diatas menunjukkan bahwa tingkat aktivitas siswa sudah mencapai 59\%, sedangkan tingkat standar nilai ketuntasan siswa masih mencapai $41 \%$, dari hasil data ini maka harus dapat ditingkatkan lagi pada siklus II. Perolehan prosentase pada tingkat aktivitas, serta tingkat standart nilai ketuntasan diperoleh dari: jumlah total setiap indikatornya dikali $100 \%$ dibagi jumlah nalai rata-rata.

Yaitu tingkat aktivitas $=\underline{1,7+1,7+1,5} \times 100 \%=59 \%$.

\section{8,3}

Sedangkan tingkat standart nilai $=\frac{1,8+1,6}{8,3} \times 100 \%=41 \%$.

Dari hasil pengolahan data pada siklus I diperoleh beberapa catatan (refleksi) sebagai berikut : (1) Pelaksanaan pembelajaran model tematik tema lingkungan dengan pendekatan kontekstual ini dapat berjalan dengan cukup lancar, akan tetapi proses dan hasil pembelajarannya masih belum optimal; (2) Siswa masih belum terbiasa dengan pembelaran menggunakanmodel tematik tema lingkungan dengan pendekatan kontekstual; (3) Hasil skor dari tes formultuf yang dicapai masih $43.3 \%$ dari jumlah siswa sedangkan standart nilai ketuntasan yang ditetapkan oleh pihak sekolah adalah $75 \%$ dari jumlah siswa, sehingga pada siklus II harus diberikan latihan-latihan formatif lebih bervariasi dan harus lebih banyak lagi, hal ini bertujuan untuk membantu siswa dalam mempermudah dalam memahami pembelajaran yang diberikan oleh guru; (4) Tingkat aktivitas siswa sudah mencapai 59\%, sedangkan tingkat standart nilai ketuntasan siswa masih mencapai $41 \%$, dari hasil data ini maka harus dapat ditingkatkan lagi pada siklus II; (5) Beberapa siswa masih ada yang yang belum berani untuk maju ke depan kelas untuk mengerjakan soal yang diberikan oleh guru; (6) Beberapa siswa masih terlihat kurang begitu aktif selama proses pembelajaran berlangsung; (7) Hasil penelitian pada siklus ini, masih banyak kekurangan dalam pelaksanaan pembelajaran sehingga peneliti dan guru harus merancang penelitian tindakan pembelajaran pada siklus II.

Tabel 3.Hasil Skor Tes Formatif Siswa pada Siklus II

\begin{tabular}{cccc}
\hline NO. & SKOR & FREKUENSI & PRESENTASE (\%) \\
\hline 1. & 100 & 4 & 13,3 \\
\hline 2. & 95 & 4 & 13,3 \\
\hline 3. & 90 & 4 & 13,3 \\
\hline 4. & 85 & 5 & 16,6 \\
\hline 5. & 80 & 3 & 10 \\
\hline 6. & 75 & 5 & 16,6 \\
\hline 7. & 70 & 3 & 10 \\
\hline 8. & 65 & 2 & 6,7 \\
\hline
\end{tabular}


Bergita

\begin{tabular}{cccc}
\hline 9. & 60 & - & - \\
\hline 10. & 55 & - & - \\
\hline 11. & 50 & - & - \\
\hline 12. & $<50$ & - & - \\
\hline & JUMLAH & 30 & 100 \\
\hline
\end{tabular}

Perolehan nilai rata-rata skor aktivitas belajar siswa selama proses pembelajaran berlangsung, dan standart nilai ketuntasan yang ditentukan oleh pihak sekolah, dari hasil data tabel pada siklus II diatas sudah terlihat bahwa sudah jelas terjadi perubahan tentang hasil belajar, dengan adanya perbaikan pembelajaran model tematik dengan tema lingkungan. Sedangkan hasil perubahan skor nilai rata-rata yang diperoleh pada siklus II yaitu sebagai berikut:

Tabel 4. Hasil Observasi Siswa pada Siklus II

\begin{tabular}{llll}
\hline NO Aspek & Hal-hal yang diamati & Nilai Rata-rata & Perubahan
\end{tabular}

Siklus I Siklus II

\begin{tabular}{|c|c|c|c|c|}
\hline \multirow[t]{3}{*}{ Aktivitas } & $\begin{array}{llr}\text { Siswa mengikuti } & \text { jalannya } \\
\text { proses pembelajaran } & \text { dengan } \\
\text { tertib dan disiplin. } & \end{array}$ & 1,7 & 2,4 & $+0,6$ \\
\hline & $\begin{array}{l}\text { Siswa mau berdiskusi dan } \\
\text { bekerjasama dengan anggota } \\
\text { kelompoknya. }\end{array}$ & 1,7 & 2,6 & +0.9 \\
\hline & $\begin{array}{l}\text { Siswa mau dan berani } \\
\text { memberikan tanggapan } \\
\text { saran terhadap hasil kerja } \\
\text { temannya. }\end{array}$ & 1,5 & 2,5 & +0.9 \\
\hline
\end{tabular}

\begin{tabular}{llllll}
\hline 2. Standar & $\begin{array}{l}\text { Siswa mendapat nilai minimal } \\
\text { Nilai } \\
\text { Ketuntasan }\end{array}$ & $\begin{array}{l}\text { memenuhi nilai ketuntasan yang } \\
\text { telah ditentukan oleh pihak } \\
\text { sekolah. }\end{array}$ & & $+0,7$ \\
& & & \\
& & & & \\
& $\begin{array}{l}\text { Siswa tidak pernah remidi dalam } \\
\text { setiap mengerjakan tugas yang } \\
\text { diberikan oleh guru. }\end{array}$ & & & $+0,8$ \\
& & & & \\
&
\end{tabular}

\begin{tabular}{llll}
\hline Rata-rata & 1,7 & 2,5 & $+0,8$
\end{tabular}

Dari hasil penelitian pada siklus II diperoleh catatan sebagai berikut : (a)Pelaksanaan Pembelajaran Model Tematik dengan tema lingkungan pada siklus II ini 
sudah dapat berjalan dengan lancar dan lebih baik dari siklus I; (b) Hasil skor tes formulatif yang dicapai sudah mencapai $83,3 \%$ dari jumlah siswa sedangkan standart nilai ketuntasan yang ditetapkan oleh pihak sekolah adalah $75 \%$ dari jumlah siswa, dari hasil inilah sudah dapat diambil kesimpulan bahwa pembelajaran tematik dengan tema lingkungan sudah berhasil; (c) Hasil nilai rata-rata dai siklus I dan siklus II mengalami kenaikan sebesar 0,8 dari rata-rata 1,7 ke 2,5; (d) Siswa sudah berani maju ke depan kelas untuk mengerjakan soal yang diberikan oleh guru; (e) Siswa sudah aktif selama proses pembelajaran berlangsung.

\section{Peningkatan Penerapan Model Pembelajaran Tematik Tema Lingkungan dengan Pendekatan Kontekstual}

Pembelajaran model tematik tema lingkungan dengan pendekatan kontekstual memang agak sulit diterima oleh siswa kelas I B SD Katolik Yos Sudarso Maumere. Dalam hal ini dapat dilihat dari hasil presentase siswa yang sebelumnya mendapatkan nilai ketuntasan pada siklus I yaitu 43,3\% dari 30siswa, padahal ketentuan dari sekolah diharuskan yang mendapat nilai ketuntasan adalah $75 \%$ dari jumlah siswa. Hal ini disebabkan karena selama ini dalam penerapan model pembelajaran yang dilakukan oleh guru-guru sekolah dasar selama ini selalu menggunakan model pembelajaran yang monoton yaitu dengan metode pembelajaran yang biasa atau konvensional dipakai dari jaman dulu seperti model pembelajaran: ceramah, tanya jawab, mencatat, dan menulis. Jadi guru tidak pernah menerapkan kegiatan pembelajaran seperti: demonstrasi, percobaan, permainan atau bahkan penemuan siswa sendiri.

Setelah dilakukan penerapan model pembelajaran tematik tema lingkungan dengan pendekatan kontekstual ini maka rata-rata hasil skor siswa berubah drastis, data ini dapat dilihat yaitu melalui perolehan skor rata-rata nilai katuntasan pada siklus I yaitu 43,3\% naik menjadi $83,3 \%$ pada siklus II, di mana presentase tersebut melebihi ketentuan sekolah. Peningkatan ini terjadi pada siswa tersebut di karenakan pembelajaran menggunakan model tematik tema lingkungan dengan pendekatan kontekstual memberi dampak positif pada pemahaman siswa serta keaktifan siswa.

Guru bisa mengajak siswa terlibat dalam pembelajaran dan memperlihatkan segala sesuatu secara jelas sehingga tidak akan terjadi salah pemahaman. Siswa yang tidak terlalu aktif dan masih malu-malu di hadapan temannya jadi bisa aktif dan percaya diri dengan dorongan dan motivasi guru. Yang awalnya kurang paham terhadap materi bisa sedikit demi sedikit memahami materi dan menambah pengetahuan mereka dari pengetahuan sebelumnya.

\section{Dampak Penerapan Model Pembelajaran Tematik terhadap Keaktifan Belajar Siswa.}

Dengan adanya model pembelajaran tematik tema lingkungan dengan pendekatan kontekstual ini dapat meningkatkan keaktifan belajar siswa di kelas I B SD Katolik Yos Sudarso Maumere. Yang mana hal ini dapat dilihat pada tabel hasil observasi yang mencapai skor rata-rata pada siklus $\mathrm{I}=1,6$ serta perubahan skor rata-rata yang ada pada 
Bergita

siklus II $=2,5$. Dari siklus I dan siklus II tersebut sudah jelas ada peningkatan nilai skor rata-rata sebesar 0,9 .

Keaktifan siswa pada pembelajaran tematik tema lingkungan ini ditunjukkan oleh: (1) Siswa mengikuti jalannya proses pembelajaran dengan tertib dan disiplin, (2) Siswa mau berdiskusi dan bekerjasama dengan anggota kelompoknya, dan (3) Siswa mau dan berani memberikan tanggapan dan saran terhadap hasil kerja temannya.

Dampak Penerapan Model Pembelajaran Tematik terhadap Standar Nilai Ketuntasan Belajar Siswa.

Dengan adanya model pembelajaran tematik tema lingkungan ini dapat meningkatkan standart nilai ketuntasan belajar siswa di Kelas I B SD Katolik Yos Sudarso Maumere. Yang mana hal ini dapat dilihat pada tabel hasil observasi dengan data tercapainya sampai mencapai skor rata-rata siklus $I=1,7$ serta perubahan pada skor ratarata yang ada pada siklus $\mathrm{II}=2,5$. Dari siklus I dan siklus II tersebut sudah jelas ada peningkatan nilai skor rata-rata sebesar 0,8 .

Standar Nilai Ketuntasan pada pembelajaran model pembelajaran tematik tema lingkungan adalah sebagai berikut:(1) Siswa mendapat nilai minimal memenuhi nilai ketuntasan yang telah ditentukan oleh pihak sekolah, (2) Siswa tidak pernah remidi dalam setiap mengerjakan tugas yang diberikan oleh guru.

\section{PENUTUP}

\section{Simpulan}

a. Penerapan model pembelajaran tematik tema lingkungan dengan pendekatan kontekstual selama proses belajar mengajar yang telah di terapkan peneliti di dalam kelas mampu meningkatkan hasil siswa. Hal ini di tandai dengan ketuntasan belajar siswa yang cukup baik dari hasil tes formulatif pada dua siklus yang di laksanakan mulai dari siklus pertama sampai kedua. Hasil belajar siswa memperoleh ketuntasan nilai $43,3 \%$ dari jumlah siswa pada siklus 1 dan meningkat menjadi $83,3 \%$ dari jumlah siswa pada siklus 2 .

b. Penerapan model pembelajaran tematik tema lingkungan dengan pendekatan kontekstual bagi siswa kelas I B di SD Katolik Yos Sudarso ini dapat meningkatkan keaktifan belajar siswa. Hal ini dapat dilihat dari hasil observasi yang mencapai skor rata-rata pada siklus $I=1,6$ serta perubahan skor rata-rata yang ada pada siklus $\mathrm{II}=$ 2,5. Dari siklus I dan siklus II tersebut sudah jelas ada peningkatan nilai skor rata-rata sebesar 0,9 .

c. Penerapan model pembelajaran tematik tema lingkungan dengan pendekatan kontekstual bagi siswa kelas 1 di kelas I B di SD Katolik Yos Sudarso ini dapat meningkatkan standart nilai ketuntasan belajar siswa. Hal ini dapat dilihat dari hasil observasi yang mencapai skor rata-rata pada siklus $\mathrm{I}=1,7$ serta perubahan skor ratarata yang ada pada siklus II $=2,5$. Dari siklus I dan siklus II tersebut sudah jelas ada peningkatan nilai skor rata-rata sebesar 0,8 .

\section{DAFTAR PUSTAKA}

Arikunto, S. 2009. Penelitian Tindakan Kelas, Jakarta: Bumi Aksara

Arikunto, S. 2006. Prosedur Penelitian Suatu Pendekatan Praktek, Jakarta: Rineka Cipta 
Serambi Akademica

Jurnal Pendidikan, Sains, dan Humaniora
Vol. 7, No. 5,

Oktober 2019
pISSN 2337-8085

eISSN 2657- 0998

Elaine, B johnson, 2007. Contekstual Teaching and Learning, Bandung: MLC

Hamalik, O, 2001. Proses Belajar Mengajar, Jakarta:Bumi Aksara

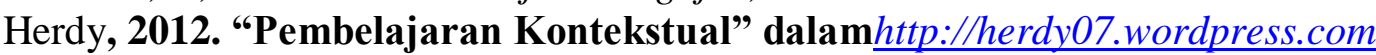

Khaeruddin, 2007. Kurikulum Tingkat Satuan Pendidikan (KTSP), Yogyakarta: Kerjasama MDC Jateng dengan Pilar Media.

Mansur, S. 2018. Pengaruh Pendekatan Jelajah Alam Sekitar (JAS) Terhadap Hasil Belajar Siswa Pada Materi Klasifikasi Mahluk Hidup di SMPK Binawirawan Maumere. Uhamka. Bioeduscience. 2 (1): 74-80. DOI: 10.29405/j.bes/7480121314

Kunandar, 2007. Guru Profesional Implementasi Kurikulum Tingkat Satuan Pendidikan (KTSP) dan Sukses dalam Sertifikasi Guru, Jakarta: Raja Grafindo Persada

Kunandar, 2008. Langkah Mudah Penelitian Tindakan Kelas, Jakarta:Raja Grafindo Persada,

Komalasari, Kokom, 2010. Pembelajaran Kontekstual, Bandung, Refika Aditama

Lexy, Moleong, 2008. Metodologi Penelitian Kualitatif, Bandung: Remaja Rosdakarya

Mansur, S. 2018. Penerapan Model Pembelajaran Kooperatif Tipe STAD untuk Meningkatkan Motivasi dan Hasil Belajar pada Konsep Ekosistem di SMA Negeri 2 Maumere. STAI Darul Kamal NW Kembang kerang. Jurnal Al-Muta'aliyah. 1 (1): 117-127. DOI: http://ejournal.kopertais4.or.id/sasambo/index.php/mutaaliyah

Mulyasa, E., 2008. Menjadi Guru Profesional, Bandung: Remaja Rosdakarya

Muslich, M, 2001. KTSP Pembelajaran Berbasis Kompetensi dan Kontekstual, Jakarta: Bumi Aksara 